\title{
COEFFICIENTS OF ENERGY AND NUTRIENT APPARENT DIGESTIBILITY OF THREE RAW AND COOKED ALTERNATIVE PLANT INGREDIENTS FOR Colossoma macropomum AND Piaractus brachypomus (SERRASALMIDAE)
}

\author{
Fred William CHU-KOO', William N. CAMARGO², Miriam Adriana ALVAN-AGUILAR', Jesse \\ TRUSHENSKI $^{3}$, Christopher C. KOHLER ${ }^{2}$ \\ 1 Instituto de Investigaciones de la Amazonía Peruana - IIAP. Programa AQUAREC. Centro de Investigaciones Fernando \\ Alcántara-CIFAB.E-mail: fchu@iiap.org.pe \\ 2 Southern Illinois University Carbondale. Fisheries and Illinois Aquaculture Center. Carbondale, IL 62904. \\ 3 Eagle Fish Health Laboratory. Idaho Department of Fish and Game.
}

\begin{abstract}
The coefficients of the apparent digestibility for dry matter, crude protein, crude lipid and gross energy in cooked and raw green plantain meal (GPM), cassava root meal (CRM), and peach palm meal (PPM) were determined for juveniles of black pacu $(60.8 \pm 6.4 \mathrm{~g})$ and red pacu $(76.3 \pm 5.0 \mathrm{~g})$. The ADC of each alternative ingredient was determined by comparison of the digestibility (based on recovery of $1 \%$ chromic oxide as an inert marker) of a reference diet (consisting of $70 \%$ of test diet and $30 \%$ of the feedstuff) against with a test $\operatorname{diet}(24.5 \%$ of crude protein). Fish were bred in a recirculation system including $42,110-\mathrm{L}$ glass aquaria (21 tanks per species) at a density of five fish per tank, and fed their respective diets to apparent satiety, twice a day. Feces were collected after 10 days in plexiglass fecal collectors. Apparent digestibility coefficients of crude protein, crude lipid and gross energy from raw and cooked GPM and CRM were low compared to values to other common vegetal ingredients like corn and wheat. Conversely, ADC values for raw and cooked PPM were, in most cases, higher than those reported in raw or cooked GPM and CRM. In comparison with other traditional feedstuffs, apparent utilization of PPM was similar to corn and higher than reported for soybean meal and wheat bran in these fish species. Peach palm meal appears to have good potential as a feed ingredient in low-cost diets for pacu species.
\end{abstract}

KEYWORDS: aquaculture, digestibility, feeding, red pacu, black pacu.

\section{COEFICIENTES DE DIGESTIBILIDAD APARENTE DE LOS NUTRIENTES Y LA ENERGÍA DE TRES INGREDIENTES VEGETALES ALTERNATIVOS CRUDOS Y COCIDOS EN Colossoma macropomum Y Piaractus brachypomus (SERRASALMIDAE)}

\begin{abstract}
RESUMEN
Los coeficientes de digestibilidad aparente (ADC) para la materia seca, proteína cruda, lípidos y energía bruta en harinas obtenidas de porciones crudas y cocidas de plátano verde (GPM), yuca (CRM) y pijuayo (PPM) fueron determinados en juveniles de gamitana $(60.8 \pm 6.4 \mathrm{~g})$ y paco $(76.3 \pm 5.0 \mathrm{~g})$. El ADC de los ingredientes alternativos fue determinado por comparación de la digestibilidad (basada en la recuperación de óxido crómico como marcador inerte) de una dieta referencial ( $70 \%$ de dieta testigo y $30 \%$ del ingrediente en estudio) versus la dieta testigo ( $24.5 \%$ de proteína bruta). Los peces fueron criados en un sistema de recirculación compuesto de 42 acuarios de vidrio de $110 \mathrm{~L}$ (21 tanques para cada especie), a una densidad de cinco peces por tanque y alimentados con sus respectivas dietas hasta la saciedad aparente, dos veces por día. Las heces fueron colectadas a los 10 días en colectores fecales. Los niveles de ADC para proteína bruta, lípidos y energía bruta registrados para las harinas crudas y cocidas de plátano y yuca fueron bajas comparadas con las existentes para otros ingredientes como el maíz y el trigo. Sin embargo, los niveles de ADC obtenidos para las harinas crudas y cocidas del pijuayo fueron en la mayoría de los casos superiores a los reportados para el plátano y la yuca. En comparación con otros ingredientes vegetales, las harinas a base de pijuayo fueron utilizadas en niveles similares a las reportadas para la soya y salvado de trigo en paco y gamitana. El pijuayo presenta mayor potencial como ingrediente de bajo costo para ser usado en dietas de alimentación del paco y gamitana.
\end{abstract}

PALABRAS CLAVE: acuicultura, digestibilidad, alimentación, paco, gamitana. 


\section{INTRODUCTION}

The black pacu Colossoma macropomum and red pacu Piaractus brachypomus are native fish species being farmed in South America (Núñez et al., 2009). Cultured in earthen ponds at stocking rates between $0.5-1 \mathrm{fish} / \mathrm{m}^{2}$, both fish species may reach 0.8 to $1 \mathrm{~kg}$ in only 6 to 8 months (Dañino et al., 2009a,b). They are generally fed extruded or pelleted diets formulated with traditional feedstuffs (fish meal, wheat derivatives, corn and soybean meal). However, prices for commercial aquafeeds are too high for most small-scale fish farmers, who comprise nearly $90 \%$ of those involved in pacu culture in the Peruvian Amazon (Chu-Koo et al., 2012). Therefore, there is an increasing need for more low-cost ingredients to be used in Peruvian aquafeeds for pacus, particularly because of the high cost of ingredients like imported soybean meal and wheat derivatives.

Traditionally, corn grains and wheat middlings are the main sources of gross energy in commercial formulated aquafeeds for pacu and other Amazonian omnivorous cultured fishes (Mori et al., 1999; Lochmann et al., 2009). Corn prices have progressively increased in the past years and wheat is not traditionally farmed in the Amazonian region and consequently must be imported from Argentina or the USA, and at a high price. In contrast, plantain (Musa paradisiaca), cassava root (Manihot sculenta), and peach palm (Bactris gasipaes) are substantial components of the local population's diet and they are grown in proximity to fish ponds. In fact, production of these plants is often so high that local prices fall to levels more suitable for livestock feed ingredients than for marketing as human staple foods (Lochmann et al., 2009).

Cassava (locally known as yuca) and its byproducts (roots, skin, leaves, etc.) are used as alternative ingredients to corn and rice in formulated diets for monogastric animals in developing countries (Nhu Phuc et al., 1995; Rosales \& Paúcar, 1996; Akinfala et al., 2002; Vieira et al., 2002), including farmed fish (Araújo-Lima \& Goulding, 1997; Alcántara \& Colace, 2001; Campos Baca \& Kohler, 2005). Plantain is used primarily for human food but also as supplemental feed for small-scale fish farming in Brazil and Peru (Alcántara \& Colace, 2001; Alcántara et al., 2003; Guimarães \& StortiFilho, 2004; Chuquipiondo \& Galdós, 2005). Approximately 15 million metric tons of bananas and 9 million metric tons of plantains are annually available for use as feedstuffs and processed plantain meal is being used in aquafeeds in Southeast Asia (Aquafeed International, 2008; Quynh Tram, 2010). In addition, peach palm (or pijuayo) is a staple food crop whose fruit provides an edible pulp for direct human consumption, flour for infant formula and baked goods, as well as serving as an ingredient in feeds for farmed animals and fish (Blanco-Metzler $e t$ al., 1992; Mora-Urpí, 1993; Clement, 1995; Mori et al., 1999; Alcántara et al., 2003).

Because Colossoma and Piaractus readily accept plant materials as food, small-scale fish farmers utilize a wide variety of agricultural byproducts, leaves, fruits and seeds to feed their fish (Alcántara \& Colace, 2002). However, little information exists with respect to these types of feedstuffs, such as their nutritional value and digestibility, the growth performance they yield, etc.

The Food and Agriculture Organization (FAO, 2007) recommended the utilization of native crops to supply the dietary needs currently obtained from imports or feeds that might be better used by humans in Latin America; and suggested the use of cassava, plantain and peach palm as potential ingredients to be used in animal diets, in order to decrease current dependence on cereals and grains (Machin, 1992). Recently, Núñez (2009) emphasized the need for conducting sustainable aquaculture in South America by promoting the culture of species whose dependence of animal protein derivatives can be far lower than current species being cultured (e.g. salmonids, shrimps). Therefore, red and black pacu are two excellent candidates for sustainable aquaculture since they can use dietary plant proteins and carbohydrates more efficiently than carnivores due to their natural frugivorous diet (Araújo-Lima \& Goulding, 1997; Lochmann et al., 2009).

Culture techniques for these and other native Amazon fishes could be advanced considerably with new information on nutrient utilization in fishes fed diets with different compositions. Although some of the basic nutrient requirements are known for serrasalmids (Fernandes et al., 2004), there is not much information on the availability of nutrients from feedstuffs of local origin. Even when cost and convenience of local feedstuffs are attractive, there is no advantage to using them in fish diets if the nutrients they contain are largely unavailable. Digestibility coefficients for many of the traditional feedstuffs used in current pacu diets have been determined (Fernandes et al., 2004). Comparative data from promising native feedstuffs would provide a nutritional basis for selecting low-cost accessible feedstuffs for use in pacu diets in the Amazon region. Knowledge about the nutrient digestibility of the food sources is important for the formulation of both experimental and practical fish diets as well as in studies to determine quantitative nutrient requirements. Furthermore, the formulation of low- 
cost fish diets requires extensive knowledge of both the chemical composition of the feedstuffs and the availability of their nutrients to the fish.

Accordingly, this study was designed to assess the apparent nutrient and energy digestibility coefficients of cooked and raw green plantain, cassava root, and peach palm, three agricultural products currently harvested and used as food sources for fish in the Peruvian Amazon.

\section{METHODS}

\section{EXPERIMENTAL SYSTEM AND FISH}

Hatchery-produced fingerlings of black pacu and red pacu were shipped from the Instituto de Investigaciones de la Amazonía Peruana-IIAP (Iquitos, Peru) to Carbondale (Illinois, USA). After a period of acclimation, they were initially trained to a commercial catfish diet (32\% crude protein) and maintained in three raceways with recirculated water for four months prior their use in the trials.

Fish were individually measured and weighed and then randomly placed in groups of five into each of 42,110 -L aquaria (21 tanks per pacu species) in a recirculation aquaculture system and allowed to acclimate to ambient conditions. During acclimation fish were fed to satiation with a standard reference diet formulated according to Fernandes et al. (2004). Then, the seven experimental diets (Table 2) were randomly assigned to triplicate aquaria in each trial. Water temperature and dissolved oxygen were measured twice per week before feeding using a Dissolved Oxygen Meter, YSI Model 52 (YSI Instrument Co. Inc., Yellow Spring, Ohio, USA). Total ammonia nitrogen, nitrite, and alkalinity levels were measured twice per week using a AQ-2 Freshwater Water Lab Kit (LaMotte Co., Chestertown, Maryland, USA). The $\mathrm{pH}$ was measured using a $\mathrm{pH} /$ temperature/mV/ORP Meter (Col-Parmer Instrument Co., Vernon Mills, Illinois, USA).

\section{EXPERIMENTAL DIETS}

Each test diet was prepared with $70 \%$ of the standard reference diet and $30 \%$ of the test ingredient. The individual test ingredients evaluated were: green plantain meal (GPM), cassava root meal (CRM), and peach palm meal (PPM), each assessed as raw and cooked products (Table 2 ).

Raw cassava roots, peach palm and green plantain were washed, peeled and chopped in thin slices (4-5 mm) and then dried at $65^{\circ} \mathrm{C}$ for $24 \mathrm{~h}$ in an oven. They were then finely ground (1-2 $\mathrm{mm})$ in a Wiley mill. For cooked ingredients, thin raw slices were boiled in water for $5 \mathrm{~min}$ before being dried and finely ground in the same manner as raw ingredients. The proximate composition of these three ingredients is shown in Table 1.

Diets were prepared in a mixer by slowly adding micronutrients (vitamin and minerals premixes) to the macro-ingredients to ensure a homogenous mixture (Table 2). About $400-450 \mathrm{~mL}$ of water was added per kilogram of diet to achieve a consistency that would produce stable pellets. A meat grinder fitted with a $3 \mathrm{~mm}$ die was used to produce the pellets, which were fan dried for $24 \mathrm{~h}$ and stored at $-18^{\circ} \mathrm{C}$ until use. The composition of the test diets is shown in Table 2.

\section{FECAL COLLECTION}

In each trial, fish were fed their respective diets for a 5-d acclimation period followed by a 10-d fecal collection period. During the fecal collection period, fish were fed to apparent satiation twice daily. Two hours after feeding, uneaten food was removed to prevent ingestion of feed that may have leached nutrients. All aquaria bottoms were siphoned in order to standardize the stress on the fish. The feces were collected the following morning at approximately 12-14 hours after the previous feeding event in specially designed fecal collector devices similar to these described by Ayala \& Kohler (1993). Daily fecal samples for each aquarium were dried in a drying oven for $6 \mathrm{~h}$ at $65^{\circ} \mathrm{C}$ to reduce moisture, and then stored frozen in aluminum pans.

\section{ANALYTICAL METHODS}

Moisture and dry matter were obtained by drying triplicate samples (approximately $250 \mathrm{mg}$ ) of diets at $135^{\circ} \mathrm{C}$ for 3 hours. Crude protein was determined on dried samples using a Kjeltec 1026 Distillation Unit (Tecator-Perstorp, Höganas Sweden). About 1-g samples were weighed in nitrogen-free paper in duplicate, and transferred to a digestion tube along with two Kjeldahl catalyst tablets. Concentrated sulfuric acid was added using a dispenser and the tubes were placed in a preheated digestion block at $420^{\circ} \mathrm{C}$ for 1 hour. After cooling, the tubes were distilled automatically in the Kjeltec 1026 Distillation Unit. The solution in the receiver flask was then titrated against $\mathrm{HCl}$ of a known concentration. Percent nitrogen of the sample was calculated using the titration volume and converted to protein using a factor of 6.25. Crude fat was determined gravimetrically following the lipid extraction according to Folch et al., (1957). Crude fiber content was determined in the Chemical Analysis Lab of the SIUC College of Animal Sciences, following standardized methods of acidalkali digestion (AOAC, 1990). 
Ash was determined gravimetrically by burning $2.5 \mathrm{~g}$ of triplicated samples at $550^{\circ} \mathrm{C}$ for 3 hours, while energy content were obtained using a Parr 1261 Bomb Calorimeter (Parr Instrument Co., Moline, Illinois, USA).

Chromic oxide recovery levels were determined by atomic absorption using standard methods used at the SIUC Wildlife Cooperative Lab (Carbondale, IL).

\section{CALCULATIONS AND STATISTICAL ANALYSIS}

The digestibility coefficient for a nutrient in either the reference or test diet and for a nutrient in each test ingredient was determined according to the formula:

$$
\operatorname{ADC}(\%)=100-\left[100\left(\% \mathrm{C}_{\text {diet }} / \% \mathrm{C}_{\text {feces }}\right) \times\left(\% \mathrm{~N}_{\text {feces }} / \% \mathrm{~N}_{\text {diet }}\right)\right]
$$

where $\mathrm{C}$ is the inert marker and $\mathrm{N}$ the nutrient. The apparent digestibility coefficients (ADC) for dry matter $\left(\mathrm{ADC}_{\mathrm{DM}}\right)$, crude protein $\left(\mathrm{ADC}_{\mathrm{CP}}\right)$, crude lipid $\left(\mathrm{ADC}_{\mathrm{CL}}\right)$ and gross energy $\left(\mathrm{ADC}_{\mathrm{GE}}\right)$ for each ingredient was calculated as:

$\operatorname{ADCi}(\%)=\mathrm{ADC}_{\text {test }}+\left(\left(0 \cdot 7 \times \mathrm{N}_{\text {ref }}\right) /\left(0.3 \times \mathrm{N}_{\mathrm{i}}\right)\right) \times\left(\mathrm{ADC}_{\text {test }}-\mathrm{ADC}_{\text {ref }}\right)$

where $\mathrm{ADCi}$ is the apparent digestibility coefficient for each ingredient expressed in terms of percentage; ADC test is the apparent digestibility coefficient of the test diet; $\mathrm{N}_{\text {ref }}$ the nutrient content of the reference diet; $\mathrm{N}_{\mathrm{i}}$ the nutrient content of each test ingredient; $\mathrm{ADC}_{\mathrm{ref}}$ the apparent digestibility of the reference diet.

The data were subjected to two-way analysis of variance (ANOVA) to test the effects of ingredient, the type of presentation and the interaction of these two variables.

If significant $(\mathrm{P}<0.05)$ differences were found in the ANOVA test, Tukey HSD test was used for pairwise comparison using SPSS version 11.5 for Windows (SPSS, Chicago, IL, USA). Results are expressed as the mean \pm standard deviation (SD) of three replicates for each treatment (diets) in each trial. The level of significance applied was $\mathrm{P}<0.05$.

\section{RESULTS}

\section{WATER QUALITY}

Water quality parameters maintained during the experiments were the following: dissolved oxygen $5.6 \pm 0.4 \mathrm{mg} / \mathrm{L}$, water temperature $27.1 \pm 0.5^{\circ} \mathrm{C}, \mathrm{pH}$ $6.7 \pm 0.1$, ammonia $0.23 \pm 0.1 \mathrm{ppm}$, nitrite $0.05 \pm$ $0.01 \mathrm{ppm}$, and alkalinity $48.9 \pm 6.4 \mathrm{ppm}$. These values are considered suitable for black and red pacu culture (Soberón et al., 2007).

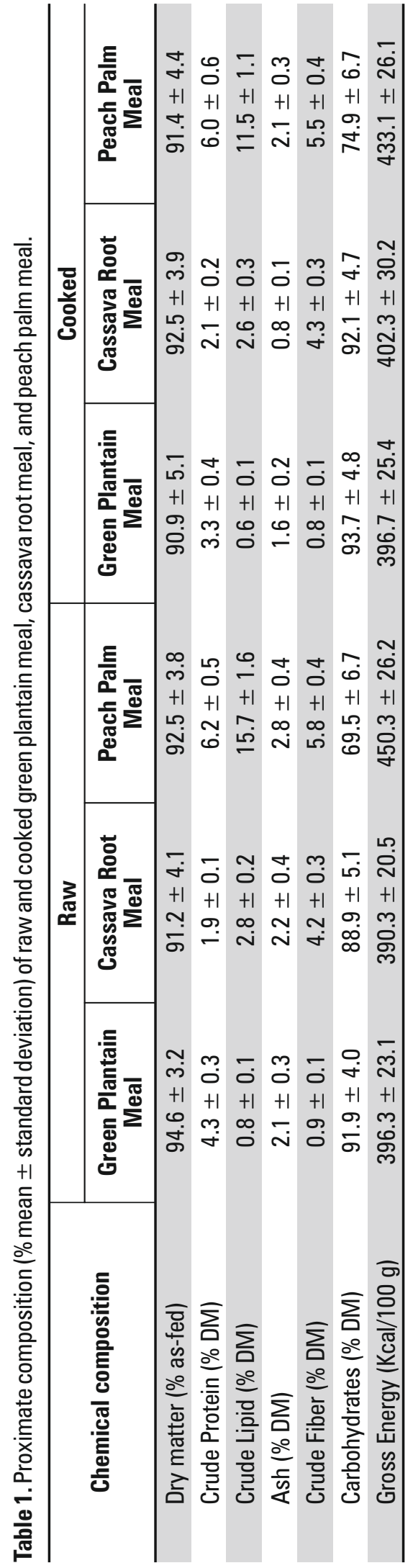




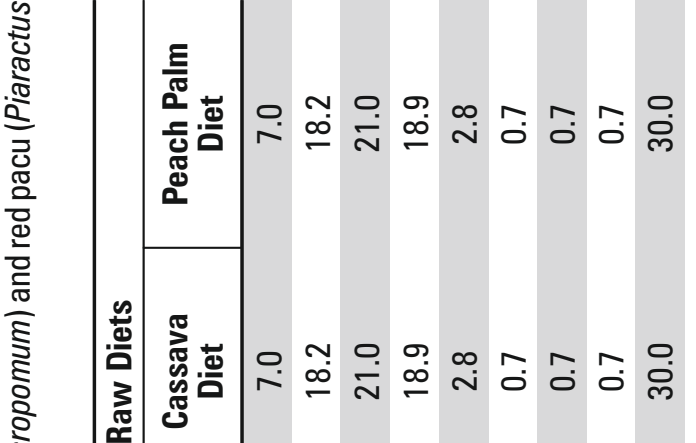

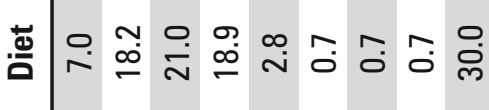

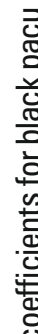

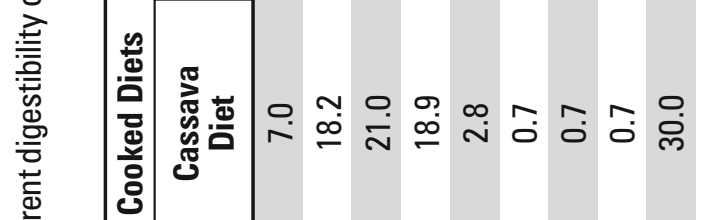

$\frac{\pi}{\frac{\pi}{0}}$

.$\frac{0}{0}$

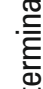

흉

क्ष

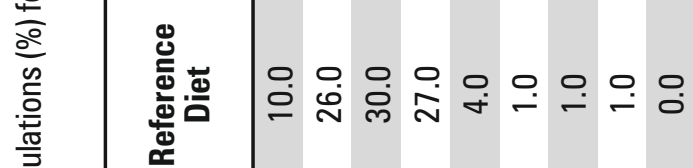

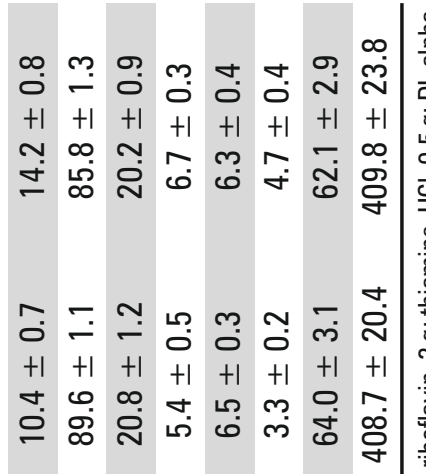

$+1+1+1+1+1+1+1$

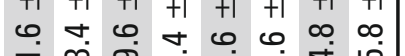

$=\infty$ ந ம்

c.

व

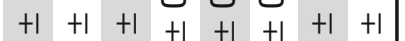

흐

$\therefore$ 舟

我

$+1+1+1+1+1+1+1+\infty$

s.

$=\infty$ வ

๘

0 - 0 o 00 c m

$\begin{array}{llllll}+1 & +1 & +1 & +1 & +1 & +1\end{array}+1+1$

๗ँ

○ 00 0

$+1+1+1+1+1+1+1+1$

m ก. 0 o $\sim$ ต m

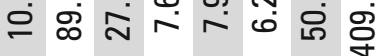

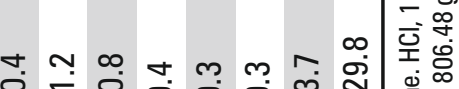

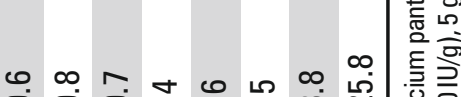

흥

尘

论

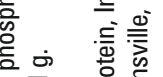

둥 홍

잉

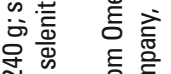

结施

密

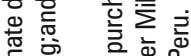

के

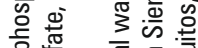

है 胥

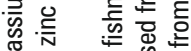

항 흥 훙

的产 苛言产

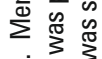

宁要 亲

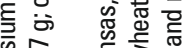

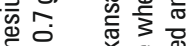

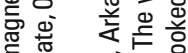

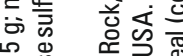

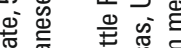

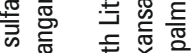

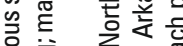

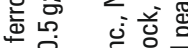

히응

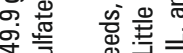

䆛

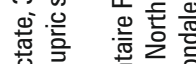

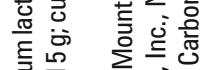

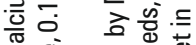

过 要

이음음

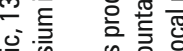

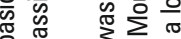

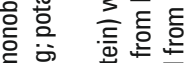

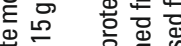

to

흥 흥 웡

응흗 बٓ

है E

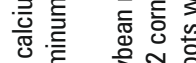

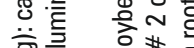

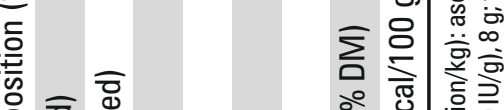

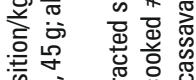

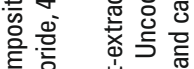

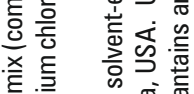

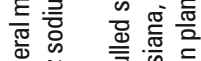




\section{APPARENT DIGESTIBILITY COEFFICIENTS}

In black pacu (Table 3), $\mathrm{ADC}_{\mathrm{DM}}$ values for the cooked ingredients ranged from $78.6 \%$ (CRM) to $89.9 \%$ (PPM); whereas raw feedstuffs ranged from as low as $74.2 \%(\mathrm{CRM})$ to as high as $87 \%(\mathrm{PPM})$, with significant differences recorded for both factors tested $(\mathrm{P}<0.001$ for test ingredients, and $\mathrm{P}=0.009$ for type of presentation, respectively). $\mathrm{ADC}_{\mathrm{CP}}$ values varied from $60.1 \%$ (CRM) to $83.3 \%$ (PPM) in cooked ingredients, and from $49.8 \%$ (CRM) to $80.1 \%$ (PPM), for raw feedstuffs. As reported for dry matter, the analysis of variance indicated that protein digestibility coefficients are significantly influenced by the dietary ingredients being tested $(\mathrm{P}<0.001)$ and also by the type of presentation $(\mathrm{P}<0.001)$.

$\mathrm{ADC}_{\mathrm{CL}}$ values were higher when compared to the other parameters evaluated. ADC values estimated for crude lipids contained in cooked ingredients ranged from as low as $84.6 \%$ (GPM) to as high as $90.7 \%$ (PPM), while $\mathrm{ADC}_{\mathrm{CL}}$ for raw feedstuffs varied from $50.5 \%$ (CRM) to $90.6 \%$ (PPM). The analysis of variance indicated that lipid digestibility is significantly influenced by the dietary ingredients $(\mathrm{P}<0.001)$, the type of presentation $(\mathrm{P}<0.001)$, and the interaction between these two variables $(\mathrm{P}=0.005)$. Gross energy digestibility for cooked ingredients varied from $47.8 \%$ (CRM) to $84.2 \%$ (PPM), whereas ADC for raw feedstuffs ranged from as low as $38.1 \%$ (CRM) to as high as $78.2 \%$ (PPM). As reported for dry matter and crude protein, the ANOVA indicated that ADC for gross energy may be significantly influenced by both factors, the dietary ingredients tested $(\mathrm{P}<0.001)$ and the type of presentation $(\mathrm{P}<0.001)$, but no significant effects $(\mathrm{P}=0.742)$ were recorded due to the interaction between these two variables according to the twoway ANOVA test.

In red pacu (Table 4), $\mathrm{ADC}_{\mathrm{DM}}$ values for cooked ingredients ranged from $82.7 \%(\mathrm{CRM})$ to $87.1 \%$ (PPM), whereas raw feedstuffs varied from as low as $82.1 \%$ (CRM) to as high as $86.2 \%$ (PPM), with significant differences recorded only for tested ingredients $(\mathrm{P}<0.001)$. No significant differences were recorded due to the type presentation $(\mathrm{P}=0.366)$ or the interaction between these two variables $(\mathrm{P}=0.424)$. Crude protein digestibility values varied from $55.7 \%(\mathrm{CRM})$ to $86.8 \%(\mathrm{PPM})$ in cooked ingredients, and from 53.1\% (CRM) to $85.6 \%$ (PPM, for raw feedstuffs. The analysis of variance indicated that $\mathrm{ADC}_{\mathrm{CP}}$ percentages are significantly influenced by the dietary ingredients being tested $(\mathrm{P}<0.001)$, and the type of presentation $(\mathrm{P}<0.044)$. However, the two-way ANOVA test yielded no significant effects of the interaction between these two independent variables $(\mathrm{P}=0.569)$.
In red pacu, the crude lipid digestibility coefficients were significantly higher for cooked and raw PPM, when compared to the other ingredients $(\mathrm{P}<0.01)$.

$\mathrm{ADC}_{\mathrm{CL}}$ values estimated for crude lipids contained in cooked ingredients ranged from as low as $56.6 \%$ (GPM) to as high as $92.2 \%$ (PPM), whereas the $\mathrm{ADC}_{\mathrm{CL}}$ of raw feedstuffs varied from $54.9 \%$ (GPM) to $90.4 \%$ (PPM). No significant differences were recorded due to the type of presentation or because of interaction between these variables $(\mathrm{P}=0.005)$.

Gross energy digestibility percentages for cooked ingredients varied from $40.9 \%$ (CRM) to $81.4 \%$ (PPM), while $\mathrm{ADC}_{\mathrm{GE}}$ for raw feedstuffs ranged from as low as $32.7 \%$ (CRM) to as high as $74.2 \%$ (PPM). The ANOVA indicated that ADC for gross energy may be significantly influenced by both factors, the dietary ingredients tested $(\mathrm{P}<0.001)$ and the type of presentation $(\mathrm{P}=0.003)$. No significant differences were recorded due to the interaction between these two variables $(\mathrm{P}=0.345)$.

\section{DISCUSSION}

The replacement of certain traditional feedstuffs used as ingredients in aquafeeds, for substitutes, has emerged as an alternative economic practice mainly in developing countries. However, the digestibility of most of these new items has yet to be studied to increase the knowledge of animal nutrition.

According to Hepher (1988), several factors may influence the digestibility of fish dietary feedstuffs. The author emphasizes that the main ones are: a) fish species, b) age/size, c) physiological conditions, d) water temperature, e) salinity, f) food composition, g) feed intake and f) particle size.

Other key factors reported to overestimate or underestimate fish digestibility are the methods of collection of feces. While passive methods tend to overestimate it, active methods such as abdominal stripping (sometimes even killing the fishes for intestine stripping) tend to underestimate ADCs (Ramsay et al., 2000).

It was found that $\mathrm{ADC}$ levels for crude protein, lipid and gross energy for cooked GPM and CRM in black pacu were always higher than ADC recorded for raw ingredients, as it was originally expected, since thermal treatments, such as boiling, typically have a positive effect on the digestibility of most nutrients in aquafeeds (Bergot, 1991; Wilson, 1994) by inhibiting antinutritional factors (ANF) that may be occurring in plant-based feedstuffs and/or facilitating the breakdown of dietary starch (Hardy, 1989). 


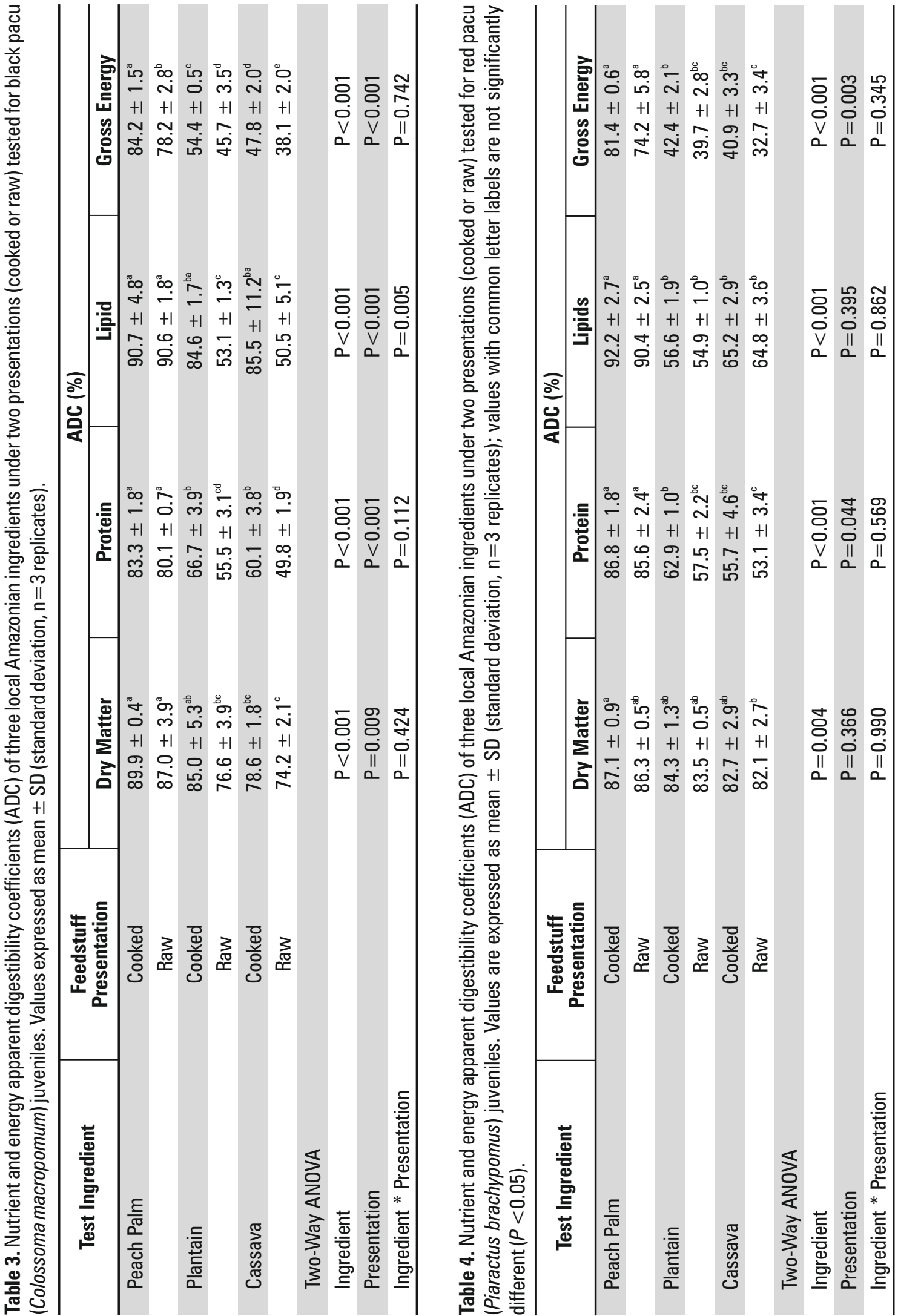


Table 5. Apparent digestibilty coefficients $(A D C)$ determined for some ingredients in black pacu (Colossoma macropomum), red pacu (Piaractus brachypomus), and pacu (Piaractus mesopotamicus) as reported by other authors.

\begin{tabular}{l|c|c|c|}
\hline \multirow{2}{*}{\multicolumn{1}{c|}{ Test Ingredient }} & \multicolumn{3}{c|}{ ADC (\%) } \\
\cline { 2 - 4 } & Dry Matter & Protein & Lipid \\
\hline Gutierrez et al. (2009) Corn (black pacu) & $82.4 \pm 1.0$ & $75.5 \pm 1.5$ & $76.2 \pm 2.4$ \\
\hline Vidal et al. (2004) Corn (black pacu) & $83.3 \pm 8.7$ & $81.5 \pm 7.9$ & ---- \\
\hline Soybean meal (black pacu) & $82.8 \pm 9.3$ & $90.4 \pm 6.4$ & --- \\
\hline Fernandes et al. (2004) Soybean meal (red pacu) & $83.7 \pm 6.9$ & $75.9 \pm 8.0$ & $63.0 \pm 6.3$ \\
\hline Corn (red pacu) & $89.1 \pm 8.2$ & $85.1 \pm 2.4$ & $83.0 \pm 1.6$ \\
Wheat bran (red pacu) & $82.1 \pm 4.7$ & $61.6 \pm 4.4$ & $82.4 \pm 6.6$ \\
Gutierrez-Espinosa \& Vásquez-Torres (2008) & ---- & $83.2 \pm 1.6$ & $59.9 \pm 2.9$ \\
Soybean meal (red pacu) & & 80.7 & 76.9 \\
\hline De Oliveira et al. (1997) Dende meal (pacu) & 54.0 & 83.4 & 97.6 \\
\hline Coco meal (pacu) & 72.6 & & \\
\hline
\end{tabular}

In contrast, $\mathrm{ADC}$ levels for dry matter, protein, lipid and gross energy for cooked and raw GPM and CRM in red pacu were surprisingly similar. However for practical terms, nutrients as well as the gross energy contained in CRM and GPM were just available for both fish species even when CRM and GPM were previously boiled, representing a limiting key factor for their future utilization in formulated low-cost compound diets for serrasalmids.

Low digestibility coefficients of CRM and GPM were unexpected outcomes since pacus are believed to efficiently utlize plant-derived nutrients such as protein, lipids and especially carbohydrates (Da Silva et al., 2002) as previous studies had reported the utilization of these ingredients in pacu diets with encouraging results (Guimarães \& Storti-Filho, 2004; Chuquipiondo \& Galdós, 2005; DelgadoVidal et al., 2009). We believe that the feces collection method used in this study (sedimentation) may provide some explanation of this unexpected result, as passive methods of fish collection tend to underestimate the nutrient and gross energy digestibility in fish (Ramsay et al., 2000). Low ADC values for crude protein recorded for CRM and GPM in black and red pacu may also be partially explained due to the high carbohydrate content of both feedstuffs. Protein digestibility tends to be depressed as the concentration of dietary carbohydrates increases (NRC 1993). Fish age/size may be another important factor involved in the low ADC recorded in this study as it was proved that digestibility in herbivore/omnivore fishes may increase with fish size/age due to associated increases in intestinal length, microflora and enzyme production and thus digestion and assimilation time (Ferraris et al., 1986; Quynh Tram, 2010). For instance, Quynh Tram (2010) proved that enzymatic production and action of proteases and amylases are typically lower during the first development stages of herbivore/omnivore fish than in the later stages, and this might also hold true for red and black pacu.

Since crude fiber of experimental diets ranged from as low as $3.3 \%$ to as high as $6.4 \%$, it cannot be assumed of having a negative effect in digestibility as reported for other fish species (Ferraris et al., 1986; Wang et al., 1985). For instance, Dongmesa et al. (2009) revealed that green plantain contains high levels of active tannins and cassava roots contain phytic acid and hydrogen cyanides. These compounds are chemical anti-nutritional factors (ANF) that limit a wide range of enzymatic reactions, particularly of the proteases (Francis et al., 2011). The presence of ANF may be partially responsible for low nutrient availability in raw GPM and CRM. In the case of tannins, which are only 50$70 \%$ deactivated by boiling (Vijayakumari et al., 1995), this could even explain the reasons for low uptake of nutrients in the cooked GPM in both fish species. As for CRM, Montagnac et al. (2009) reported that phytate and polyphenols contained in cassava roots interfere with digestion and uptake of nutrients.

Sowetan \& Oyewole (2009) mentioned the fact that a new plant-based feedstuff is eaten by a fish is 
nothing less than just a sign of acceptability. Usually, fish nutritionists pay more attention on the analyses of protein and fiber as indicators of feedstuff quality when more importance should be paid to the presence of compounds such as ANF which may affect levels of dietary protein and fiber uptake in fish (Sowetan \& Oyewole, 2009; Francis et al., 2001).

Additionally, low enzymatic activity may have occurred into the digestive tracts of both fish species, as a result of our feeding schedule during the experiment (fish were fed once daily), as it is known that digestive enzymes response may be affected by the feeding period, since changes in enzyme synthesis and activity in fishes can be observed after a long feeding period (Kaushik et al., 1995).

Conversely, black and red pacu individuals seemed to utilize the nutritional content of PPM more efficiently, regardless of presentation (raw or cooked). Only in black pacu, gross energy was more efficiently utilized when it was under the form of cooked PPM, which suggests no thermal pretreatment is absolutely necessary to improve PPM nutrient availability for formulated pacu aquafeeds.

Without a question, digestibility of a particular feedstuff depends on the species of fish tested. A clear example of that is the study performed by Abu et al. (2010) in which, they found that CRM can effectively replace corn as a dietary source of energy in low-cost aquafeeds for hybrid African catfish Clarius gariepinus. Complementarily, Udo \& Umoren (2011) found that boiled CRM is well digested by the same catfish as ADC values for dry matter, crude protein and energy were 88.5,94.4, and $73.2 \%$ in that species. Madalla (2008) also pointed out that CRM could replace up to $75 \%$ of wheat meal in a Nile Tilapia Oreochromis niloticus diets without significantly affecting fish growth performance.

Higher ability of effectively utilizing CRM, showed for African catfish and Nile tilapia may be a result of drastic physiological differences respect to pacus, specifically in digestive amylases and proteases composition and/or function. For instance, De Almeida et al. (2006) reported that the proteolytic activity in black pacu is mainly detected in the stomach, where acidic proteases prevail, as nonspecific protease activity in black pacu's intestine is very low since it like other herbivores/omnivores fish) does not express a considerable number of alkaline proteases, likely because its diet doesn't contain high levels of protein. However, most fish have better proteolytic activities into alkaline $\mathrm{pH}$ levels (De Almeida et al., 2006), placing the stomach as the main organ to digest protein in black pacu.
As has been said, the search of new ingredients for sustainable small-scale aquaculture feeds is an increasing need in most developing countries as feeding cost is the most expensive limiting factor for fish production (Adelizi et al., 1998). For instance in Pakistan, Asad et al. (2005) evaluated the digestibility of canola and guar meal in rohu (Labeo rohita), and determined that ADC for dry matter and protein were higher for canola when compared to guar meal (dry matter $70.3 \pm 0.1$ vs. $59.9 \pm 0.7$; crude protein $60.7 \pm 2.4$ vs. $50.3 \pm 0.9$, respectively). In Brazil, Henry-Silva et al. (2006) studied the digestibility of two aquatic macrophytes (Eichornia crassipes and Pistia stratiotes) in Nile tiapia (Oreochromis niloticus) and found that average ADC of crude protein were $59.2 \%$ for $E$. crassipes; and $52.2 \%$ for $P$. stratiotes, respectively, with no significant differences observed between the ADC of the plants ingredients. Finally in Nigeria, Osuigwe \& Okoro (2008) determined the ADC crude protein and gross energy of processed (boiled) and unprocessed (raw) mucuna seed meal (Mucuna cochinchinensis) in hybrid catfish (Heterobranchus longifilis $\mathrm{x}$ Clarius gariepinus). It was found that average ADC of crude protein and gross energy were 46.3 and $63.1 \%$ for boiled; and 40.2 and $41.2 \%$ for raw mucune seed meal, respectively. The results reported in the three studies cited only noted the low nutrient availability of these alternative feedstuffs tested for rohu, Nile tilapia and hybrid catfish. Although the nutrient availability may be limiting in these feedstuffs, now that this information is known, they may be better utilized (or avoided, as necessary) in locally produced aquafeeds.

Digestibility coefficients of the traditional feedstuffs used in pacus compound diets have been previously determined by Fernandes et al. (2004) and Gutiérrez et al. (2009). When compared to other common feedstuffs, both protein and lipid ADC of PPM are quite superior of those reported for soybean meal and wheat bran in red pacu and similar to ADC values estimated for corn. As for black pacu, dry matter, protein and lipids ADC values reported for cooked PPM revealed to be even better than ADC showed by Gutiérrez et al. (2009) for corn in the same species (Table 4). Without a doubt, peach palm's natural abundance in the Amazon region makes it economically viable for aquaculture purposes contributing to help small-scale farmers to reduce feeding cost, which remarkedly is the most critical limitation for the development of aquaculture in the Peruvian Amazon nowadays. As a general rule, ADC values obtained for GPM and CRM were always lower than ADC values reported for corn and wheat bran in both fishes (Fernandes et al., 2004; Gutiérrez et al., 2009). 
Comparisons between ADCs for PPM, GPM and CRM obtained in this study and the ADCs obtained by other authors in black and red pacu are showed in Table 3.4. Again, only ADC levels of PPM are clearly superior to those obtained for alternative and common feedstuffs such as dende meal, wheat and similar to corn. In fact, using peach palm as a feedstuff is nothing new. Mori-Pinedo et al. (1999) used PPM in three different levels (replacing corn while raising black pacu fingerlings in Brazil), having demonstrated that PPM meal can completely substitute corn without negatively affecting fish growth and body composition.

An additional advantage of PPM is its low cost. Compared with corn grains and wheat derivatives, PPM can be inexpensive in the Brazilian, Colombian, and Peruvian Amazon, and its nutrient and energy apparent digestibility values suggest that it can be used at high levels of replacement for corn (as suggested by Mori-Pinedo et al., 1999) or wheat derivatives (as suggested by Lochmann et al., 2009), in diets for either black or red pacu.

In conclusion, evaluation of the ADC for dry matter, crude protein, crude lipid and gross energy indicated that PPM (cooked or raw) is the most digestible indigenous feedstuff for black and red pacu when compared to raw or cooked CRM and GPM. Energy and nutrient ADCs obtained in this investigation support PPM as the primary choice for low-cost pacu aquafeeds in the Peruvian Amazon.

\section{LITERATURE CITED}

Abu, O.M.G.; Sanni, L.O.; Erondu, E.S.; Akinrotimi, O.A. 2010. Economic viability or replacing maize with whole cassava root meal in the diet of hybrid catfish. Agricultural Journal, 5(1):1-5.

Adelizi, P.D.; Rosati, R.R.; Warner, K.; Wu, Y.V.; Muench, T.R.; White, M.R.; Brown, P.B. 1998. Evaluation of fish-meal free diets for rainbow trout, Oncorhynchus mykiss. Aquaculture Nutrition, 4: 255-262.

Akinfala, E.O.; Aderibigbe, A.O.;\& Matanmi, O. 2002. Evaluation of the nutritive value of whole cassava plant as replacement for maize in the starter diets for broiler chicken. Livestock Research for Rural Development, 14(6): 23-30.

Alcántara, F.B.; Chávez C.V.; Rodríguez, L.C.; Camargo, W.N.; Kohler, C.C.; Colace, M.; Tello, S.M. 2003. Gamitana (Colossoma macropomum) and Paco (Piaractus brachypomus) culture in floating cages in the Peruvian Amazon. World Aquaculture Magazine, 34(4): 22-24.
Alcántara, F.B.; Colace, M.B. 2001. Piscicultura, seguridad alimentaria y desarrollo en la carretera Iquitos-Nauta y el río Tigre. Valorando y preservando nuestros peces amazónicos. Instituto de Investigaciones de la Amazonía Peruana. Iquitos. Perú. 83p.

AOAC. 1990. Official methods of analysis. 15th edition. Association of Official Analytical Chemists, Arlington, VA.

Aquafeed International. Banana meal and banana powder in aquafeeds.http://www.aquafeed.co. uk/press_release_story.php?press_release $=43$. Accessed on 27 February, 2015.

Araújo-Lima, C. A. R. M.; Goulding, M. 1997. So Fruitful a Fish: Conservation and Aquaculture of the Amazon's Tambaqui. Columbia University Press. New York City.

Asad, F.; Salim, M.; Shahzad, K.; Noreen, U. 2005. Estimation of apparent digestibility coefficient of guar, canola and meat meal for Labeo rohita. International Journal of Agriculture and Biology, 7(5):816-819.

Ayala, C.; Kohler, C.C. 1993. Protein digestibility and amino acid availability of fish meal fed to largemouth bass infected with intestinal acanthocephalans. The Progressive FishCulturist, 55(4): 275-284.

Bergot, F. 1991. Digestibility of native starches of various botanical origins by rainbow trout (Oncorhynchus mykiss). In: S.J. Kaushik \& P. Luquet (eds.) Fish Nutrition in Practice. IV International Symposium on Fish Nutrition and Feeding, INRA, Paris. p. 857-865.

Blanco-Metzler, A.; Montero-Campos, M.; Lowery, M.; Mora-Urpí, J. 1992. Pejibaye: recetas, valor nutritivo, conservación, e industrialización. Instituto Tecnológico de Costa Rica. Centro de Información Tecnológica, Cartago, Costa Rica. $35 \mathrm{p}$.

Campos-Baca, L.; Kohler, C.C. 2005. Aquaculture of Colossoma macropomum and related species in Latin America. American Fisheries Society Symposium 46:541-561.

Chu-Koo, F.; Rodríguez, C.L.; Kohler, C.C. 2012. Insumos vegetales empleados en la alimentación de peces: Una síntesis de la experiencia peruana. In: Agudelo, C.E. \& F. Duponchelle (eds.). Comunicaciones del III Coloquio de la Red de Investigación sobre la Ictiofauna Amazónica RIIA. p.174-180.

Chuquipiondo, J. M.; Galdós, A. 2005. Influencia de la harina de plátano Musa paradisiaca L. en el crecimiento de alevinos de gamitana Colossoma macropomum (Cuvier, 1818). Undergraduate 
Thesis. Universidad Nacional de la Amazonía Peruana. UNAP. Iquitos, Peru. 79p.

Clement, C. R. 1995. Pejibaye Bactris gasipaes (Palmae). In: J. Smartt and N. W. Simmonds (eds.). Evolution of crop plants, 2nd Ed. Longman, London. p. 383-388.

Dañino, P.A., Nash, R.L.; Chu-Koo, F.; MoriPinedo, L. 2011a. Crecimiento, conversión alimenticia y sobrevivencia de paco (Piaractus brachypomus) cultivado en estanques con y sin revestimiento de geomembranas en la Amazonía peruana. In: J. Núñez, F. Chu-Koo, J. Porto, \& C.R. García-Dávila (eds.). Comunicaciones del II Workshop sobre Biología de las Poblaciones de Peces de la Amazonía y Piscicultura. p. 148154.

Dañino, P.A., Nash, R.L.; Chu-Koo, F. 2011b. Rendimiento productivo de la gamitana (Colossoma macropomum) cultivada en estanques con y sin revestimiento de geomembranas en la Amazonía peruana. In: J. Núñez, F. Chu-Koo, J. Porto, \& C.R. GarcíaDávila (eds.). Comunicaciones del II Workshop sobre Biología de las Poblaciones de Peces de la Amazonía y Piscicultura. p. 155-161.

Da Silva, J.M.C.; Rylands, A.B.; Da Fonseca, G.A.B. 2005. The fate of the Amazonian areas of endemism. Conservation Biology, 19(3): 689-694.

De Almeida L.C.; Lundstedt, L.M.; Moraes, G. 2006. Digestive enzyme responses of tambaqui (Colossoma macropomum) fed on different levels of protein and lipid. Aquaculture Nutrition, 12: 443-450.

Delgado-Vidal, F.K.; Gallardo-Collí, A.; CuevasPérez, L.; García-Ulloa, M. 2009. Crecimiento compensatorio en tilapia Oreochromis niloticus posterior a su alimentación con harina de plátano. Avances en Investigación Agropecuaria, 13(2):55-70.

Dongmesa, E.; Steinbronn, S.; Francis, G.; Focken, U.; Becker, K. 2009. Investigations on the nutrient and antinutrient content of typical plants used as fish feed in small scale aquaculture in the mountainous regions of Northern Vietnam. Animal Feed Science and Technology, 149:162-178.

Fernandes, J.B.K.; Lochmann, R.; Alcántara, F.B. 2004. Apparent digestible energy and nutrient digestibility coefficients of diet ingredients for pacu Piaractus brachypomus. Journal of World Aquaculture Society, 35:237-244.

Ferraris, R.P.; Catacutan, M.R.; Mabelin, R.L.; Jazul, A.P. 1986. Digestibility in milkfish,
Chanos chanos (Forsskal): Effects of protein source, fish size and salinity. Aquaculture, 59(2): 93-105.

Folch, J., Lees, M.; Sloane-Stanley, G. H.1957. A simple method for the isolation and purification of total lipids from animal tissue. Journal of Biochemistry, 226:497-509.

Food and Agricultural Organization of the United Nations. 2007. Crop production in Latin America and the Caribbean, 2006. FAOSTAT [WWW Document]. URL http://faostat.fao.org/site/567/ DesktopDefault.aspx?PageID $=567$. [accessed on September 19, 2015].

Francis, G.; Makkar, P.S.H.; Becker, K. 2001. Antinutritional factors present in plant-derived alternate fish feed ingredients and their effects in fish. Aquaculture, 199: 197-227.

Guimaraes, S. F.; A. Storti-Filho. 2004. Agricultural and forest products as supplementary feeding for tambaquí in polyculture with jaraqui. Pesq. Agropec. Bras., 39(3):293-296.

Hardy, R.W. 1989. Diet preparation. In: J.E. Halver (editor). Fish Nutrition, 2nd edn. Academic Press, San Diego, CA. p. 475-548.

Hepher, B. 1988. Nutrition of Pond Fishes. Cambridge University Press, New York, 388p.

Henry-Silva, G.G.; Camargo, A.F.M.; Pezzato, L.E. 2006. Digestibilidade aparente de macrófitas aquáticas pela tilápia-do-nilo (Oreochromis niloticus) e qualidade da água em relação às concentrações de nutrientes. Revista Brasileira de Zootecnia, 35(3): 641-647.

Kaushik, S.J.; Cravedi, J.P.; Lalles, J.P.; Sumpter, J.; Fauconneau, B.; Laroche, M. 1995. Partial or total replacement of fish meal by soybean protein on growth, protein utilization, potential estrogenic or antigenic effects, cholesterolemia and flesh quality in rainbow trout. Aquaculture, 133:257-274

Lochmann, R.; Chen, R.; Chu-Koo, F.W.; Camargo, W.; Kohler, C.C. 2009. Effects of carbohydraterich alternative feedstuffs on growth, survival, body composition, hematology, and non-specific immune response of black pacu, Colossoma macropomum, and red pacu, Piaractus brachypomus. Journal of the World Aquaculture Society, 40: 33-44.

Machin D.H. 1992. Overview of needs and justification for use of roots, tubers, plantains and bananas in animal feeding. In: Machin D. \& S. Nyvold (eds.). Roots, tubers, plantains and bananas in animal feeding. Proccedings of the FAO Expert Consultation, Cali, 1991. FAO Animal Production and Health Paper, 95, Food 
and Agriculture Organization of the United Nations, Rome. p. 1-10.

Madalla, N. 2008. Novel Feed Ingredients for Nile Tilapia (Oreochromis niloticus L.). Ph.D.dissertation. University of Stirling. Scotland.

Montagnac, J.A.; Davis, C.R.; Tanumihardjo, S.A. 2009. Processing techniques to reduce toxicity and antinutrients of cassava for use as a staple food. Comprehensive Reviews In Food Science and Food Safety, 8:17-27.

Mora-Urpí, J. 1993. Diversidad genética en pejibaye. II. Origen y domesticación. In: J. Mora-Urpí, L. T. Szott, M. Murillo \& Patiño, V. M. (eds.). IV Congreso Internacional sobre Biología, Agronomía, e Industrialización del Pijuayo. Editorial de la Universidad de Costa Rica, San José. p. 21-29.

Mori-Pinedo, L. A.; Pereira-Filho, M. \& OliveiraPereira, M.I. 1999. Substituição do fubá de milho (Zea mays, L) por farinha de pupunha (Bactris gasipaes, H.B.K) em racões para alevinos de tambaqui (Colossoma macropomum, Cuvier 1818). Acta Amazonica 29(3): 447-453.

Nhu Phuc, B.H.; van Lai, N.; Preston, T. R.; Ogle, B.; Lindberg, J. E. 1995. Replacing soybean meal with cassava leaf meal in cassava root diets for growing pigs. Livestock Research for Rural Development 7(3): 89-101.

Núñez, R.J. 2009. Domestication of new economically important Amazonian fish species. CahAgric. 18(2-3): 136-143.

Osuigwe, D.I.; Okoro, A.C. 2008. Apparent digestibility coefficients of differentially processed Mucuna cochinchinensis (Lour.) seed meal by hybrid catfish (Heterobranchus longifilis $\mathrm{x}$ Clarias gariepinus) fingerlings. Advances in Science and Technology, 2(2):6370.

Quynh Tram, N.D. 2010. Evaluation of local feed resources for hybrid catfish (Clarias macrocephalus x C. gariepinus) in smallholder fish farming systems in central Vietnam. Doctoral Thesis Swedish University of Agricultural Sciences. Uppsala, Sweden.
Ramsay, J.M.; Castell, J.D.; Anderson, D.M.; Hebb, C.D. 2000. Effects of fecal collection methods on estimation of digestibility of protein feedstuffs by winter flounder. North American Journal of Aquaculture, 62(3):168-173.

Rosales, J. M.; Páucar, R. 1996. Uso de la cáscara de yuca en raciones para cerdos en crecimiento. Folia Amazónica, 8(2):105-118.

Soberón, M.L.E.; Chu-Koo, F.; Alcántara, B.F. 2007. Parámetros hematológicos, crecimiento y composición corporal de juveniles de gamitana Colossoma macropomum (Cuvier, 1818) cultivados bajo tres densidades de siembra. Folia Amazónica, 16(1-2): 35-45.

Sowetan, K.O.; Oyewole, O.E. 2009. The need for adequate processing to reduce the antinutritional factors in plants used as human foods and animal feeds: A review. African Journal of Food Science, 3(9):223-232

Udo, I.U.; Umoren, U.E. 2011. Nutritional evaluation of some locally available ingredients use for least-cost ration formulation for African catfish (Clarias gariepinus) in Nigeria. Asian Journal of Agricultural Research, 5: 164-175.

Vieira, J. J. R.; Zeoula, L. M.; Do Prado, I. N.; Geron, L. J. V. 2002. Replacement of corn for cassava meal (Manihot esculenta, Crantz) in the Holstein Calves Diets. Digestibility and Energy value. Revista Brasileira de Zootecnia, 31(1):205-212.

Vijayakumari, K.; Siddhuraju, P.; Janardanan, K. 1995. Effect of various water treatments on certain antinutritional compounds in the tribal pulse, Dolichos lablab var vulgaris L. Plant Foods Hum. Nutr., 48:17-29.

Wang, K.; Takeuchi, T.; Watanabe, T. 1985. Optimum protein and digestible energy levels in diets for Tilapia nilotica. Bulletin of the Japanese Society of Scientific Fisheries, 51(1): 141-146.

Wilson, R. P. 1994. Utilization of dietary carbohydrate by fish. Aquaculture, 124:67-80.

Recibido: 20 de Abril del 2016

Aceptado para publicación: 27 de Mayo del 2016 